\title{
The Effectiveness of E-Learning Implementation Using Social Learning Network Schoology on Motivation \& Learning Achievement
}

\author{
JW.Nugroho Joshua ${ }^{1)}$, I Putu Agus Swastika ${ }^{2)}$, Ni Made Estiyanti ${ }^{3)}$ \\ STMIK Primakara \\ Bali, Indonesia \\ joshua@primakara.ac.id
}

\begin{abstract}
-the advancement of technology and the openness of the internet access in many places in Indonesia, making the shift in styles of learning and acquiring knowledge. Significant growth on such access also has changed the way everyone connected, communicate with each other and develop a social community. Unlike previous generations, college students in today's era found many learning resources, both from his tutor at the College as well as from fellow students, also from other learning sources outside his College. The fact of this openness requires a new approach for a lecturer in the College to adopt a way of delivering his teaching, so the learning objectives can be achieved. One such implementation is implementing e-learning using the Social Learning Network. The purpose of this study is to see to what extent the effectiveness of the e-learning implementation on motivation and learning achievements of students. The research results showed that the learning opportunities has the greatest role in the motivation of learning, followed by collaborative learning. A high learning motivation using Social Learning Network, Schoology became a highly influential variable on learning achievements of Students in STMIK Primakara Bali
\end{abstract}

Keywords-e-learning;

effectiveness;e-learning implementation; Social Learning Network; Schoology

\section{INTRODUCTION}

The implementation of education system based on the needs of the learners as Gibbs in Sparrow [1] being demands on curriculum implementation in the college. To produce a profile of graduates as expected, a College must have set out a system of -the best- curriculum and teaching that can be provided by the College. Various activities are organized and policies implemented in the academic field to answer the needs necessary to equip learners with the knowledge, skills and attitudes, until one day ready to become graduates who are ready to work in the community.

Certainly, the practice of education and teaching at the School of Informatics Management and computer engineering has been designed with structured that individually adapted to the challenges of the times. Nowadays, the study field of information systems and Informatics Engineering is amazingly fast and massive when compared to the fields outside of this study.
When tracedfarther, the traditional class (room) and conventional teaching methods became limited. Rapid development -technology, material and psychological immediacy of learners-create a lecturer need to keep renewing the Adaptive capability with the development of studies in accordance with the movement of the industry. To adjust to the speed, that is then needed in ways that are more adaptive, so a lecturer can convey the main analytical study materials to the learners effectively, and learners can absorb much of their learning materials with a guide of his tutor.

Learning by utilizing the online classroom (online class) is an effort to encourage learning can be conducted anytime and anywhere. Learning in an online classroom is not replacing face-to-face learning undertaken together with your lecturer in the classroom, but by utilizing the online classroom, students will get extra or enrichment ('s) material that would complement the conventional learning. Through Learning with a model like this, learners will be encouraged to be more active and creative. Active and creative in the sense, that in the online class, learners are expected to want to search for, read, and understand the materials from a variety of digital learning resources. In addition, learners can be deduced, creating, and sharing knowledge as well as works that have been made to the other participants. Via online classes, learners are expected to be able to discuss and collaborate in virtual groups [2].

SEAMOLEC in the Guide wrote, on the dimensions of learning, technology can be used to expand the range of learning, increase the speed of learning, and improve the efficiency of learning. Presence technology provides the impact on individual ease in learning, with the presence of: connectivity, collaboration, interaction, Flexibility, opportunity, Motivation [2]. Presence technology has supported the process of teaching and learning become more rich and meaningful, when used in the right way.

\section{LITERATURE REVIEW}

\section{A. E-Learning}

Hartley wrote that E-Learning is a type of teaching and learning that delivering of learning materials to allow students 


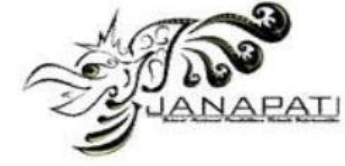

to use the internet, intranet, or other computer media networks [1].

E-learning is often referring to the use of information and communication network in the process of teaching and learning or the delivery of learning programs, training, or education with the use of electronic means [2]. A number of other terms are also used to describe the model of teaching and learning, including online learning, virtual learning, distributed learning, networking and web-based learning. Basically, all referring to the educational process utilizing elearning information and communication to mediate as well as asynchronous synchronous learning and teaching activities [3].

E-learning is also defined as the use of ICT networks deliberately in the process of teaching and learning. Other terms used to define models of teaching and learning, online learning, virtual learning, as well as network or web-based learning [4].

In its application, E-learning can serve as extra / learning enrichment: (supplement), substitute a portion of learning (complement), or substitute a whole learning (replacement). Then there are two different types of implementation of elearning, e-Learning means Synchronous interaction of trainers and trainees at the same time over the internet. Synchronous technologies also allow people to interact Conference with peers and experts. Synchronous E-learning is like a virtual classroom that duplicates the capabilities found in a real classroom and the second is that the Asynchronous eLearning allows the student to complete the Web-based training on his own time and schedule, without live interaction with the trainer. People learn anywhere at anytime There is complete flexibility with asynchronous training, which comes in two forms, Discussion Groups and self paced. [5].

In order to differentiate it from the conventional class, a class in the ICT-based learning environment also known by the term online classes (online class). In the online classroom, e-learning is utilized as an attempt to supplement learning in order to enrich the material taught in conventional class [2].

The learning model which combines the process of teaching and learning in the conventional classroom with online classes, called blended learning. Blended learning is a combination of various ' medium ' learning (technology or activity) to create an optimal learning for students. The term ' blended ' stated that the conventional learning implemented by teachers in the classroom, enriched with a variety of digital sources [6].

In order to support the virtual class using a variety of software/applications/systems those are generally web-based. Generally known two types of applications i.e. applications Learning Management System (LMS) and Learning Content Management System (LCMS). However, in the subsequent developments, as the widespread utilization of Social Network (SN) in particular Facebook, comes the application of Social Learning Network (SLN) as an alternative form of the virtual class [2].
ISSN 2087-2658

atika (JANAPATI)

Volume 5, Nomor 1, Maret 2016

\section{B. The purpose of E-learning}

Technology is one of the supporting media as a means to deliver and develop a science that aims to facilitate students in learning and improve the quality of learning activities. Bates in Hartoyo[3] suggests that the goal of implementing elearning approaches as follows: a. Increase access to learning opportunities (increase access to learning opportunity) and flexibility of students in learning. In this case, e-learning and learning opportunities can increase the flexibility of students in learning through a variety of means and methods of learning to use; b. Improving the quality of learning (enhance the general quality); c. Developing skills and competencies (develop skills and competencies) required of students as well as provide the necessary digital skills in the fields of science, profession, or their careers; d. Accommodate various styles or how to learn (to meet the learning needs/styles) students; e. Increase the effectiveness of the funds (cost effectiveness), especially at the level of secondary education.

\section{Social Learning Network}

Previously, the LCMS and LMS software are widely used in the implementation of e-learning. But along with the conditioner of networking people through social media, then changes also occur in learning activities. LMS and LCMS are considered less able to adapt, inflexible and does not provide a feature of social relations. The need was answered in further technological developments, the concept of social relations and social care began to be applied and provide a meaningful influence towards collaboration and learning.

Through the application of this concept in technology, students are now able to collaborate, improve cognitive ability, and his social skills. Starting from thatconcept,then come up the new paradigm in the study, as Halimi has written,called CSSL (Social Computer Supported Learning). In it, there is a concept of Social Learning Network that aims to encourage its users to have a new experience in learning to use social networking (Social Network), which has been equipped with the concept of corporate social responsibility [2] [8]

Social networking or social network $(\mathrm{SN})$ is a ' network' which contains the social interactions and interpersonal relationships. The more detail, the $\mathrm{SN}$ is an application or a page allows users to communicate with one another by means of exchange of information, comments, messages, images, or audio-video. In Social Network Sites (SNS) such as Facebook or Twitter, user facilitated to do interaction, communication, and collaboration [7]. By communicating through this media, interpersonal interaction is becoming closer. Therefore, based on the excess of this is the variety of social networking sites are encouraged to be utilized in the study [3].

Social learning network (SLN) or social networking for learning, according to Kordesh refers to interpersonal connections through interactions with the main objectives for 


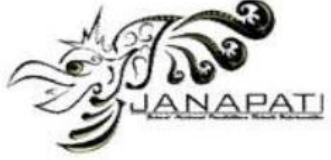

the development of knowledge [9] [2]. In more detail, SLN refers to several phenomena.

The use of Social Network (SN) for learning in formal education. The use of the Social Network of learners in a collaboration/discussion conducted informally.

The use of pages that are specifically designed for learning through social networks (Social Learning Network or SLN).

The use of SLN specifically developed by teachers.

\section{Schoology}

Schoology (www.schoology.com) is one of several types of Social Learning Networks (SLNs) circulating in the world of the World Wide Web.Schoology is a medium to carry out learning online. Schoology combines some features of the Learning Management System (LMS) and some of the features of social networking (Social Network), became a medium learning in an attractive and easy to use, later known as Social Learning Networks (Social Learning Networks). The concept is similar like Edmodo, however, in the e-learning thing schoology has a lot of advantages [11]. Building e-learning with Schoology is also more favorable when compared to using Moodle because it does not require the hosting and management (more users friendly). Certainly not as complete as the moodle feature, but for online learning at the school have been very adequate. As for the features owned by Schoology is as follows: Courses, Group Discussion, Resources, Quiz, Attendance and Analytics [7]

\section{E. Learning Motivation}

The word motivation comes from the Latin movere, which means the move. Motivation explains what makes people do things, make them do it anyway, and assist them in completing tasks. Related to Pintrich, this means that the concept of motivation is used to describe the desire to behave, the direction of behavior (choice), the intensity of behavior (efforts, ongoing), and completion or achievements indeed [1].

According to Santrock, motivation is the process that gives the spirit, direction, and persistence of behaviour. [1]. There are two aspects of this Santrock opinion, i.e., Extrinsic Motivation, that is, do something to get something else (how to achieve a goal) and intrinsic motivation, namely internal motivation to do something for the sake of something himself (itself) [3].

Students who have the motivation of learning will depend on whether such activities have interesting content or a fun process. Essentially, the learning motivation involves learning objectives and related strategies in achieving the learning objectives [1].

Some of the benefits of the application of E-Learning for learners in learning opportunities [2] are, E-learning gives more opportunities for learners to learn, receive enrichment learning materials and repeating material independently on the material placed database learning. More specifically to the learners to college while working he would be greatly helped by learning materials which can he learn independently first.
ISSN 2087-2658

Volumik Informatika (JANAPATI)

Volume 5, Nomor 1, Maret 2016
Study on learning collaboration [1] shown, the idea of collaborative learning begins from the perspective philosophical concept learning. To be able to learn, one must have a spouse. In 1916, John Dewey, wrote a book "Democracy and Education" which that class is a mirror of society and serves as a laboratory for learning about real life [3].

Gokhale defines that "collaborative learning" refers to the method of teaching in which students in one group that varies levels of his skills in cooperation in small groups toward common goals [1]. So learning-collaboration is a strategy of learning in which students with a variety of the multilevel cooperation in small groups towards one goal. In this group the students help each other between one another. A collaborative learning situation so there is an element of positive dependence to achieve success [10]. The use of ELearning -Social Learning NetworkSchoology-, is very close with collaborative discourse. Not only on the exchange of learning materials, but on the social web makes it easy for every Schoology learners and also his tutor can communicate and exchange ideas during the learning process.

In terms of assessment transparency, E-learning can be designed with an assessment at once (real time), after a student tested the ability of the results of his studies. However, the assessment can also be seen throughout the learning process, activity assignments, discussions and other projects can transparently in view. In this case there is no task when it has been uploaded and then,a lecturergave reasoned yet accepts the task. The third of the above give influence on the learning motivation of students

\section{F. Learning Achievement}

The high of learning motivation has effect on the Achievement of learning. Achievement is measured by the ability of learners in absorbing lessons on the course and gets a value above the required passing grade from lecturers. The results of the learning are individual mastery levels of learning to the materials as a result of the change in behavior after following lessons based on the teaching objectives to be achieved. The results of this research study only with regard to the results of a cognitive domain study which will be measured by tests and be achieved in learning [11].

Arif Gunarso, suggests that the learning achievements are the maximal effort achieved by someone after carrying out efforts to learn. The results of the study are pointing at the learning achievements, learning achievement, whereas it is a great indicator of the existence and the degree of change in the behavior of students [3].

The relationship with learning effectiveness results presented by Dunne, that the effectiveness of learning has two characteristics. The first characteristic is "facilitate pupils learn" something useful, such as facts, skills, values, concepts or something desired learning outcomes. Second, that their 


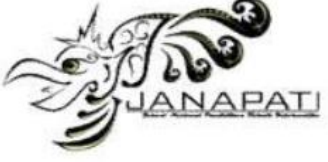

skills are recognized by the competent judge as teacher, tutor or supervisor, the learners own [2].

\section{PROBLEMS}

As the flagship of excellent and nurturing specialist, innovative and globally graduates in the field of information technology, STMIK Primakara has implemented E-Learning using Social Learning Network Schoology on teaching and learning activities. The problem is, to what extent the effectiveness of implementation influence of e-learning using Social Learning NetworkSchoology on motivation and learning achievements of students in STMIK Primakara?

\section{PROBLEMS LIMITATION}

The Learning motivation of the Study examined only sourced from the factors of learning opportunities, learningcollaboration and transparency of assessment by using ELearning, Schoology. The research location is STMIK Primakara, Bali

\section{HYPOTHESIS}

From theoretical examination, then build a model and hypotheses.

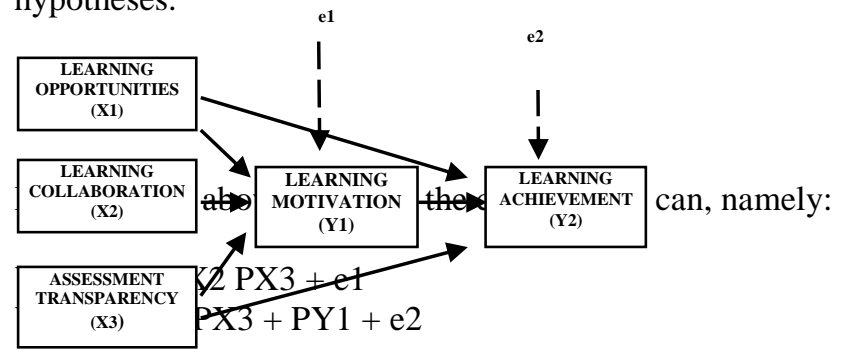

The hypothesesare formulated as follows:

1. There is the influence of learning opportunities, learning, collaboration and transparency of assessment of learning motivation.

2. There is the influence of learning opportunities, collaborative learning, the assessment transparency and learning-motivation towards learning achievements of students that showed the effectiveness of the implementation of E-Learning using Social Learning Network, Schoology.

\section{RESEARCH METHODS}

This research is descriptive research, using a survey. The survey was conducted using a questionnaire as a data collection tool that is given to undergraduate students of STMIK Primakara. Through stratified random sampling in the Department of information systems, Accounting information systems, and Informatics Engineering. Validity and reliability test, questionnaire, data analysis used SPSS 20.0.

\section{RESULTS AND DISCUSSION}

Respondents who responded to this research amounted to 40 students, divided into 10 students from Informatics Engineering, 20 students of Information System, and 10 students of Accounting Information Systems. 22 people from a number of the respondents are students who have been working (the night class). After going through the stages of test validity and reliability of the instrument, and are considered valid and reliable. So to answer the problem of hypothesis test conducted research that obtained:

From the result of Correlations using SPSS 20.0, learning motivation (Y1) have a relationship with other causal variables. The Sig value (2-tailed) all of which are smaller than the value of $\alpha(0.05)$. So, with learning achievements' (Y2), also has a significant relationship with other causal variables.

\section{Causal Chain Analysis:}

Y1 = PX1 (learning opportunities) + PX2 (collaborative learning) + PX3 (assessment transparency)

\begin{tabular}{|c|c|c|c|c|}
\hline Model & $\mathrm{R}$ & $\begin{array}{c}\mathrm{R} \\
\text { Square }\end{array}$ & $\begin{array}{l}\text { Adjusted R } \\
\text { Square }\end{array}$ & $\begin{array}{l}\text { Std. Error of the } \\
\text { Estimate }\end{array}$ \\
\hline 1 & $.655(a)$ & .429 & .381 & .546 \\
\hline
\end{tabular}

On the Table I above, the value of determination coefficient or $\mathrm{R}$ Square is 0.429 or $42.9 \%$. These values indicate that the influence magnitude of variables of learning opportunities, learning collaboration and assessment transparency against learning motivation variable is $42.9 \%$. In other words, the magnitude of the influence of other variables (e1) is $100 \%$ $42.9 \%=57.1 \%$ or $=0.571$

TABLE II. TABLE OF Y1 ANOVA

\begin{tabular}{|c|c|r|r|r|r|c|}
\hline \multirow{2}{*}{ Model } & & $\begin{array}{c}\text { Sum of } \\
\text { Squares }\end{array}$ & \multicolumn{1}{c|}{ df } & $\begin{array}{c}\text { Mean } \\
\text { Square }\end{array}$ & F & Sig. \\
\hline \multirow{3}{*}{1} & Regression & 8.055 & 3 & 2.685 & 9.017 & $.000(\mathrm{a})$ \\
\cline { 2 - 7 } & Residual & 10.720 & 36 & .298 & & \\
\cline { 2 - 7 } & Total & 18.775 & 39 & & & \\
\hline
\end{tabular}

b. Dependent Variables: learning motivation

Table of Y1 ANOVA above, is for testing whether the causal chain model is linear.Hypothesis: $\mathrm{H} 0=$ the linear tidal causal chain Model, H1 = linear causal chain Model. Sig $(0000)<\alpha$, then H0 is rejected. So, the causal chain model is linear

\begin{tabular}{|c|c|c|c|c|c|c|}
\hline \multirow[b]{2}{*}{$\begin{array}{l}\text { Mo } \\
\text { del }\end{array}$} & & \multicolumn{2}{|c|}{$\begin{array}{l}\text { Un-standardized } \\
\text { Coefficients }\end{array}$} & \multirow{2}{*}{$\begin{array}{c}\text { Standardized } \\
\text { Coefficients } \\
\text { Beta } \\
\end{array}$} & \multirow{2}{*}{$\mathrm{t}$} & \multirow{2}{*}{$\begin{array}{c}\text { Sig. } \\
\text { Std. } \\
\text { Error }\end{array}$} \\
\hline & & B & $\begin{array}{c}\text { Std. } \\
\text { Error }\end{array}$ & & & \\
\hline \multirow[t]{3}{*}{1} & (Constant) & -789 & 1.770 & & -.446 & .659 \\
\hline & $\begin{array}{c}\text { Learning } \\
\text { opportunities }\end{array}$ & .256 & .108 & .318 & 2.379 & .023 \\
\hline & $\begin{array}{l}\text { Learning } \\
\text { collaboration }\end{array}$ & .265 & .121 & .306 & 2.197 & .035 \\
\hline
\end{tabular}




\begin{tabular}{|l|r|r|r|r|r|}
\hline $\begin{array}{c}\text { Assessment } \\
\text { transparency }\end{array}$ & .030 & .016 & .263 & 1.857 & .041 \\
\hline
\end{tabular}
a Dependent Variable: learning motivation

The result of $\mathrm{Y} 1$ Coefficients indicating the magnitude of the influence of each causal variable against $\mathrm{Y} 1$ (motivation). On the Beta value, the influence of $\mathrm{X} 1$ variable (learning opportunities) is $0.318, \mathrm{X} 2$ variable (learning collaboration) is $0.306, \& \mathrm{X} 3$ variable (assessment transparency) is 0.263 . The influence of all these variables is significant, because the column value Sig is smaller than the value of $\alpha(0.05)$

The second causal chain model

$\mathrm{Y} 2=\mathrm{PX} 1$ (learning opportunities) + PX3 (assessment transparency) + Y1 (learning motivation)

TABLE IV. Y2 MODEL SUMMARY

\begin{tabular}{|c|c|c|c|c|}
\hline Model & $\mathrm{R}$ & R Square & $\begin{array}{c}\text { Adjusted R } \\
\text { Square }\end{array}$ & $\begin{array}{c}\text { Std. Error of the } \\
\text { Estimate }\end{array}$ \\
\hline 1 & $.798(\mathrm{a})$ & .637 & \multicolumn{3}{|c|}{.607 } & .672 \\
\hline
\end{tabular}

In Y2 Model Summary table above,the values of the determination coefficient or $\mathrm{R}$ Square is 0.637 or $63.7 \%$. These values indicate the influence magnitude of variables of assesment transparency, learning opportunities \& learning motivation towards learning achievements variable is $63.7 \%$. In other words, the influence of other variables (e1) is $100 \%$ $63.7 \%=36.3 \%$ or 0.363

TABLE V. TABLE OF Y2 ANOVA
\begin{tabular}{|c|c|r|r|r|c|c|}
\hline \multirow{3}{*}{ Model } & & $\begin{array}{c}\text { Sum of } \\
\text { Squares }\end{array}$ & \multicolumn{1}{c|}{ df } & $\begin{array}{c}\text { Mean } \\
\text { Square }\end{array}$ & F & Sig. \\
\hline \multirow{3}{*}{1} & Regression & 28.533 & 3 & 9.511 & 21.081 & $.000(\mathrm{a})$ \\
\cline { 2 - 7 } & Residual & 16.242 & 36 & .451 & & \\
\cline { 2 - 8 } & Total & 44.775 & 39 & & & \\
\hline
\end{tabular}
a. Predictors: (Constant), learning motivation, learning opportunities, assessment transparency

b Dependent Variable: learning achievemen

Table of Y2 ANOVA was used to test whether the causal chain model is linear.Hypothesis: $\mathrm{H} 0=$ the linear tidal causal chain Model, H1 = linear causal chain Model. Sig $(0000)<\alpha$, then $\mathrm{HO}$ is rejected. So, the causal chain model is linear

\begin{tabular}{|c|c|c|c|c|c|c|}
\hline \multirow[b]{2}{*}{$\begin{array}{l}\text { Mo } \\
\text { del }\end{array}$} & \multirow[t]{2}{*}{ 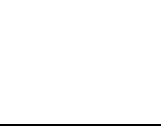 } & \multicolumn{2}{|c|}{$\begin{array}{c}\text { Unstandardized } \\
\text { Coefficients }\end{array}$} & \multirow{2}{*}{$\begin{array}{c}\begin{array}{c}\text { Standardized } \\
\text { Coefficients }\end{array} \\
\text { Beta }\end{array}$} & \multirow{2}{*}{$\mathrm{t}$} & \multirow{2}{*}{$\begin{array}{c}\text { Sig. } \\
\text { Std. } \\
\text { Error }\end{array}$} \\
\hline & & B & $\begin{array}{l}\text { Std. } \\
\text { Error }\end{array}$ & & & \\
\hline \multirow[t]{4}{*}{1} & (Constant) & -6.580 & 2.178 & & -3.021 & .023 \\
\hline & $\begin{array}{c}\text { Learning } \\
\text { opportunities }\end{array}$ & .357 & .142 & .287 & 2.505 & .017 \\
\hline & $\begin{array}{l}\text { Assessment } \\
\text { transparency }\end{array}$ & .059 & .020 & .333 & 2.886 & .007 \\
\hline & $\begin{array}{c}\text { Learning } \\
\text { motivation }\end{array}$ & .605 & .193 & .392 & 3.141 & .003 \\
\hline
\end{tabular}

The result of $\mathrm{Y} 2$ Coefficientsabove indicating the influence magnitude of each causal variable against the Y2 (learning achievements). On the Beta value, the influence of
$\mathrm{X} 1$ variable (learning opportunities) is $0.287, \mathrm{X} 3$ variable (assessment transparency) is 0.333 and y1 variable (learning motivation) is 0.392. Influence of all these variables is significant, because the column value Sig is smaller than the value of $\alpha(0.05)$

The results of statistical tests above can be grouped into:

\section{The first causal chain model}

- X1 (learning opportunities) gives a direct influence on Y1 (learning motivation) of 0.318

- X2 (collaborative learning) gives a direct influence on Y1 (learning motivation) is 0.306 . The relationship between $\mathrm{X}$ 1 with $\mathrm{Y} 1$ is 0.493

- X3 (assessment transparency) gives a direct influence on Y1 (learning motivation) of 0.263 .The relationship between $\mathrm{X} 1$ with $\mathrm{Y} 1$ is 0.484

- Causal variables X1, X2 and X3 simultaneously giving influence on Y1 of 0.429

- The influence of other variables (e1) to Y1 of 0.571

The second causal chain model:

- X1 (learning opportunities) gives a direct influence on the Y2 (learning achievements) of 0.287 . The relationship between $\mathrm{X} 1$ with $\mathrm{Y} 2$ is 0.574

- X3 (assessment transparency) gives a direct influence on the Y2 (learning achievements) of 0,333.The relationship between the X3 with Y2 is 0.609

- Y1 (learning motivation) gives a direct influence on the Y2 (learning achievements) of 0.392.The relationship between $\mathrm{X} 1$ with $\mathrm{Y} 1$ is 0.689

- Causal variables X1, X3, and Y1 simultaneously give influence on the $\mathrm{Y} 2$ of 0.607

- The influence of other variables (e2) against the Y2 of 0.363

\section{The indirectinfluence}

- X 1 (learning opportunities) gives an indirect influence on the Y2 (learning achievements) via Y1 (learning motivation) of $0.318 \times 0.392=0.111$.

- X 2 (collaborative learning) gives an indirect influence on the Y2 (learning achievements) via Y1 (motivation of learning) by $0.306 \times 0.392=0.119$

- X 3 (assessment transparency) gives an indirect influence on the Y2 (learning achievements) via Y1 (learning motivation) of $0.263 \times 0.392=0.104$

\section{CONCLUSION}

Based on results of hypothesis statistical test above, visible that learning opportunities variable on the implementation of E-Learning using Social Learning Network Schoology, has a big role of giving learning motivation, 


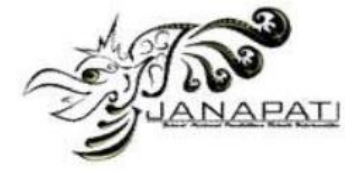

followed by learning collaboration variable and has learning achievement influence on learners.

The high of learning motivation simultaneouslyby using Social Learning NetworkSchoology, became a highly influential variable on the learners in the learning achievements of STMIK Primakara students.

\section{REFERENCES}

[1] Ramadhani, Mawar (2012).Efektivitas Penggunaan Media Pembelajaran E-Learning Berbasis Web Pada Pelajaran Teknologi Informasi Dan Komunikasi Terhadap Hasil Belajar Siswa Kelas X Sma Negeri 1 Kalasan. Skripsi, Program Studi Pendidikan Teknik Informatika Fakultas Teknik Universitas Negeri Yogyakarta

[2] SEAMOLEC (2014) Draf Buku Siswa Simulasi Digital. SEAMOLEC

[3] Nu'man, A.Z (2014) Efektifitas Penerapan E-Learning Model Edmodo Dalam Pembelajaran Pendidikan Agama Islam Terhadap Hasil Belajar Siswa (Studi Kasus : Smk Muhammadiyah 1 Sukoharjo). Duta.com ISSN : 2086-9436 Volume 7 Nomor 1 September 2014

[4] Stockley, Derek. (2003). How OE-learning Definition and Explanation (E-learning, Online Training, Online Learning) online Learning Is Revolutionizing K-12 Education and Benefiting Students. Retrieved
ISSN 2087-2658

urnal Nasional Pendidikan Teknik Informatika (JANAPATI)

Volume 5, Nomor 1, Maret 2016
January 21, 2015, from http://www.derekstockley.com.au/elearningdefinition.html

[5] Som Naidu (2006) E-Learning - A Guidebook of Principles, Procedures, and Practices. 2 Revised Edition, CEMCA

[6] Josh Bersin (2004) The Blended Learning Book: Best Practices, Proven Methodologies, and Lessons Learned. September 2004, Pfeiffer

[7] Greenhow, Robelia, \& Hughes (2009).Learning, teaching, and scholarship in a digital age Web 2.0 and classroom research: What path should we take now?SAGE Publications

[8] Huang(2010) Exploring the role Social Media and Knowledge Management Processes in Organizational Learning. http://www.isls.org/cscl2015/papers/MC-0188-Poster-Qi.pdf

[9] Kordesh, A Richard (2000). Esperanza Familiar. A UniversityCommunity partnership as Social Learning Network.http://www.huduser.org/periodicals/cityscpe/vol5num1/kordesh .$p d f$

[10] Srivastava, Ekta, Agarwal Nisha (2013) E-learning: New trend in Education and Training. International Journal of Advanced Research (2013), Volume 1, Issue 8, 797-810

[11] Aminoto, Tugiyo, Pathoni Hairul (2014). Penerapan Media E-Learning Berbasis Schoology Untuk Meningkatkan Aktivitas dan Hasil Belajar Materi Usaha dan Energi Di Kelas XI SMA N 10 Kota Jambi. Jurnal Sainmatika Vol 8 No 12014 